\title{
The Psychological Violence Against Girls and Women
}

\author{
Dr. Darina Çoni-Kacollja \\ Universiteti "Aleksandër Xhuvani" Elbasan, Albania \\ Email: darinakacollja@yahoo.com
}

Doi:10.5901/ajis.2016.v5n3s1p91

\begin{abstract}
This study is focused mostly on the psychological and emotional violence against girls and women. The implementation of the study is based on the use of the quantitative research method by spreading and completing the survey with 650 respondents from 24 to 60 years old. The detailed study aims to explore the causes and conditions which favor violence as a necessity to understand the roots of these social phenomena. This implies a comprehensive analysis of social, economical, political and sub-cultural factors which affect in the implementation of it. From the data of our survey there are some results: nearly 63.0 percent of the respondents said that they had suffered psychological violence. Insults, shouts and threats are actions which happen more frequently and the respondents say that they are the most disturbing elements. Most girls and women suffer from the psychological violence within their family. This kind of violence is mainly caused by men, by their husbands, fathers, brothers.
\end{abstract}

Keywords: psychological violence, girls and women, violence within the family, husband, children, physical violence.

\section{Introduction}

The sociologist Rose Maria Calla, who is a lecturer at the University of Trento has stated that: "The psychological violence is harder to be identified because it leaves no visible traces and it can only be defined as: offences, insults, humiliation, destruction or willful damage of an object, systematic refusal to do the housework or the educational control (of children) in everyday life and as the restriction of personal freedom and movement" (Corradi, C., 2008:225). In our environments, violence is generally considered as something that is not harmful and it should be accepted in this way. People are aware of its existence not only within their families, but even in the main institutions. The psychological violence is sometimes more harmful than the physical one. Often, it is not immediately obvious. In some severe cases, it can reach up to a person's suicide.

\section{The Diffusion of Psychological Violence}

The psychological violence is the most pervasive concern in the district of Elbasan. Our survey data show that: approximately $63.0 \%$ of respondents said that they had suffered psychological violence. Insults and shouting are actions that occur more often and for therespondents they are very disturbing.

In general, the violator is the husband, the father or the brother, who exercise psychological violence against girls and women and sometimes, when this kind of violence does not work, the physical violence is used against them. Males often have been educated since childhood with this kind of behavior against girls and women, and they see this attitude as something normal in emphasizing their leading role in the family.

As emphasized by the World Health Organization (WHO): "Men exercise violence against women as a method to stop them step out of their traditionally assigned role, or when they feel that the women can be a threat to their supremacy" (Corradi, C., 2008:69).

The male, psychologically violating the female, suppresses her, by transforming her in an inferior being,who cannot react or act against this violence. In the moment that women and girls find the force and courage within to react in order to stop this violence, the male uses the physical violence, because it feels to him like his authority is being diminished. Often, after reinstating his authority, the male apologizes, saying that it will not be repeated again, but in reality the cycle repeats itself. The strategies for keeping the violated girls and women are different in different people, and it seems that they are part of the personality of the male. This is emphasized by the Italian analysts, Giuseppe Ferrari and Valentina Penati: "The strategies used by those who decide to violate another individual are cunning and aim, first of all, to make 
possible the non-reaction of the victim against the violence. Often, especially within the family, the first victim has an emotional relation; therefore it is difficult to identify the subtle line that divides a relation from psychological violence. The attacker sends ambiguous messages, which often says one thing and means another, putting this way, with his maneuvers, the victim in a state of confusion and incompetence to understand what is going on. There is no possibility for clarification, because the interruption of bilateral communication is another maneuver that the aggressor uses. Thus, the violated feels guilty for what is going on and makes the efforts to change in order not to become anymore a cause of violence. If she tries to react after a long and continuous period of violence, she is accused of being contentious and sick" (2011:4).

Psychological violence prevails in the family and is the more concerning, not only from the sophisticated strategies used, but because it is caused by a close person that knows very well the weaknesses of the victim and knows where to use the words. As stated by the analysts Giuseppe Ferrari and Valentina Penati: "The psychological violence is used by a person who is very acquainted with the victim, knows where are the weak points, knows what to say and how to say it, knows how to do the worst, because he knows the time when the word will hurt the most, because the violator is someone the victim trusts, loves him and in whom she leans for support" (2011:4)

\section{Gender Relation and Psychological Violence}

From, the data of research, around $87.5 \%$ of the respondents confirm that they have been violated by males.

Approximately $54.7 \%$ of the respondents confirm that they have been violated by the husbands. From the data we can conclude that in the gist of violence against the woman stays the gender relation that is imposed to the woman because of the social hierarchy and gender roles, a hierarchy that transforms the woman in the property of the husband (or the latter in "defender" or "discipliner" of the woman).

Males in patriarchal societies have been educated since childhood how to behave with women; they learn since the beginning the manners they should use towards sisters, so that they will be obedient and later they start using the same methods towards their wives. From the data of research, it results that $8.2 \%$ of the respondents have confirmed that the brother is the person that has exercised violence against them. According to the sociologist Zyhdi Dervishi: "Still in Albanian society it is considered as an important "function" of older brothers taking care or tutoring the younger sisters, even the right of exercising violence against them if they do not obey to the "code" of the orders of the family's males. Such a tutoring is reinforced especially during the last 10 years, because the idea that younger or older brothers "have the task of preserving the honor of their sisters", "to not allow them to fall into the road of shame", meaning prostitution. In such a "climate" extremely tensed, many parents, especially fathers, justify and time after time incentivize the vigilance and violence of their sons towards their daughters, especially in the villages" (2009:57). By practicing since childhood, males achieve the level of "professionalism" in causing violence against girls and women and isolating them from the society.

Women and girls are violated psychologically by the males for a long time - first they are violated in childhood by their fathers and brothers, then after married, it seems normal and cannot distinguish the start of a new psychological violence.

This exercise of violence in a part of the women and girls starts to cause problems with their personality, trust in themselves, by causing this way in many occasions depression. A woman that cannot react against violence suffers from psychical problems. More often she can suffer from guilt. They, in every occasion and for everything, feel themselves guilty. They hear this statement everyday from their husbands. Through violence men keep women subordinated, and at the same time keep them closed within their homes. They are obliged to stay home, to take care of the other members of the family, and in many cases they do not have time to take care of their own needs. Even when the violated starts telling their friends, sisters and relatives about the situation, often asking for help, the violator stars joking, in the effort of changing the facts.

Fearing that the wife might tell her friends about what happens and can be influenced by them, protesting against the domination of the husband, part of the husbands find the solution in not letting their girls and women go out with their friends, not even contact with them. So starts for the girls and women an isolation induced by the fathers and husbands. Other causes of isolation of girls and women are the phenomena occurring after the 1990s, like increased unemployment and the events threatening the public security and order, murders, thefts, rapes, human trafficking, etc. Using this situation as a justification, maintaining that something bad things might happen in the street, like molestation, robbing and rapes, part of the girls and women were locked home by their family males. This results from the study data, where the findings show that $6.9 \%$ of the respondents stated that the most concerning action is not allowing them to go out with 
friends.

The above are not the only factors that influenced in isolating girls and women within the house premises. Another cause is jealousy. Even when men do not succeed in closing their wives at home, they become obsessive and call them at any time to ask their whereabouts, who they are with, what they are doing, and alike. These obsessive men go further by controlling their wives' cell phones. These findings result in the survey, where $10.2 \%$ of the respondents consider as very disturbing the control of their husbands about their whereabouts at every moment. Therefore, these wives start to lose trust in people, due to violence, and feel incompetent to carry any other task out of their homes. In women going through such violence signs of depression start showing, they are not interested of doing the chores, and do not feel capable of working outside their homes.

\section{Conclusion}

Psychological violence against daughters and wives is very much spread. They are mainly violated by the husband, father, brother and males in general. There are some factors that influence this violence, like patriarchal mentality, jealousy, not allowing women to work, etc. Preparing a national strategy on how to fight these factors, and more importantly fighting these factors, will make possible lowering violence against girls and women as the most vulnerable part of the society.

\section{References}

Dervishi, Zyhdi: Gratë në syrin e ciklonit të sfidave dhe perspektivave. Shtëpia Botuese "Emal", Tiranë,2009

Ferrari, Giuseppe; Penati, Valentina: "Il Mobbing e le violenze psicologiche" Edizione Ferrari Sinibaldi, Milano 2011

Corradi, Consuelo: I Modeli sociali della violenza contro le donne, Franco Angeli 2008

Dahrendorf, Ralf : Njeriu sociologjik, Shtëpia Botuese "Plejad", Tiranë, 2006

Dahrendorf, Ralf: Konflikti shoqëror modern, Shtëpia Botuese "Dituria", Tiranë 1997.

Davies, Miranda: Dhuna dhe gratë, Shtëpia Botuese "Dituria", Tiranë 20 